\title{
Studi Hasil Pelatihan Analisis Video dan Tool Pemodelan Tracker pada Guru MGMP Fisika Kabupaten Agam
}

\author{
Asrizal $^{1)}$, Yohandri $^{2)}$, Zulhendri Kamus ${ }^{3)}$ \\ Jurusan Fisika FMIPA Universitas Negeri Padang \\ asrizal_unp@yahoo.com
}

\begin{abstract}
Experiment is important in physics to explain and describe a physical phenomenon and its characteristics. For this reason physics teachers should conduct the physics experiment activities to motivate students in learning and to improve scientific process skills, scientific attitudes, and student understanding in physics learning. However, in the experiment activities of physics were found many problems such as experiment equipment was insufficient, there is no equipment, equipment can't operated well, and so on. An alternative solution to solve this problem was to do the video analysis and modeling tool tracker on physics teacher. The purpose of this research was to investigate the effects of the implementation the tracker video analysis and modeling tool on physics teachers. The research design was pretest and postest for one group sample. The sample of research was 26 physics teachers of Physics MGMP teacher in Agam district of West Sumatera. Instruments to collect the data consist of pretest and postest sheet, performance assessment sheet of video analysis product and questionnaires sheet of physics teachers. Data analysis techniques include descriptive statistical analysis, normality test, homogeneity test and paired comparison test for one group sample. From the data analysis, it can be stated that: 1). the average value of video analysis products from physics teachers is 85.10 and this value can be classified into very good category, 2). the average value of responses of physics teachers on training implementation of video analysis and tool modeling is 73.81 and this average value can be grouped into good category, and 3). the implementation of video analysis training of object motion video by using tracker software is effective to improve the understanding the physics MGMP teachers in Agam district on learning material of tracker video analysis and modeling tool, but the average value of understanding still in the low category.
\end{abstract}

Keywords : Video analysis, Modeling tool, Tracker, Physics experiment

This is an open access article distributed under the Creative Commons 4.0 Attribution License, which permits unrestricted use, distribution, and reproduction in any medium, provided the original work is properly cited $\odot 2018$ by author and Universitas Negeri Padang.

\section{PENDAHULUAN}

Fisika merupakan suatu pengetahuan yang menarik di dunia. Alasannya adalah ilmu fisika mampu menjelaskan bagaimana kerja-kerja dunia. Disamping itu fisika juga mampu menje laskan hubungan besaran-besaran di dunia nyata (Halliday, 2011). Karena itu fisika seharusnya ilmu pengetahuan yang menarik bagi siswa.

Eksperimen merupakan bagian penting dari Fisika. Hal ini dapat ditinjau dari pengertian dari Fisika. Fisika adalah suatu ilmu pengetahuan eksperimental (Young, 2012). Pengertian lain, fisika adalah suatu ilmu pengetahuan yang didasarkan pada observasi-observasi eksperimen tal (Zitzewitz, 2005). Sebagai tambahan, fisika didasarkan pada pengukuran dari besaran-besar an fisika (Halliday, 2011). Karena Fisika meru pakan ilmu yang didasarkan pada observasi eksperimen maka seharusnya buku-buku fisika dilengkapi dengan berbagai variasi kegiatan eksperimen baik di rumah atau di laboratorium (Serway, 2012). Pengertian ini mengindikasikan bahwa kegiatan eksperimen adalah penting dalam fisika.

Esensi dari fisika adalah untuk mendeskrip sikan dan memverifikasi hubungan antara besar an-besaran fisika. Hubungan-hubungan tersebut sering sederhana (Young, 2012). Sebagai contoh hubungan antara jarak dengan waktu pada suatu benda bergerak, hubungan antara temperatur dengan waktu pada suatu benda dipanaskan, hubungan antara tegangan dengan waktu pada pengisian kapasitor, hubungan tekanan dengan kedalaman pada suatu zat cair yang diam dan sebagainya. Kebenaran dari suatu hubungan antara besaran fisika dan nilai parameter yang tidak diketahui dapat ditentukan melalui ekspe rimen. Dengan demikian deskripsi dan verifikasi dari suatu fenomena fisika erat kaitannya dengan eksperimen. 
Studi terhadap fisika sangat berharga dalam kehidupan karena didukung oleh bebeberapa alasan. Pertama, fisika mendeskripsikan materi dan interaksi-interaksi dasarnya, banyak ilmu pengetahuan alam dibangun pada fondasi dari hukum-hukum fisika. Kedua, dalam dunia tekno logi yang pesat sekarang ini, beberapa peralatan penting dapat dipahami dengan benar hanya dengan pengetahuan yang didasarkan pada fisika. Dengan mempelajari fisika, seseorang memperoleh keterampilan yang berguna pada disiplin ilmu yang lain. Ketiga, sumber daya masyarakat terbatas sehingga penting untuk menggunakan fisika dengan cara-cara berman faat pada proyek-proyek ilmiah. Terakhir, dengan mempelajari fisika seseorang dapat mengembangkan suatu penginderaan keindahan dari hukum-hukum fundamental fisika yang mengatur alam semesta (Giambattista, 2010).

Mengingat pentingnya eksperimen dalam fisika, seharusnya guru-guru dapat melaksana kan kegiatan eksperimen dengan baik untuk meningkatkan keterampilan proses sains dan sikap ilmiah siswa. Namun kondisi nyata di sekolah kegiatan eksperimen belum dapat dilak sanakan dengan baik. Dari hasil diskusi dengan lima guru fisika SMAN 1 kabupaten Agam diperoleh informasi bahwa peralatan laborato rium fisika kurang, peralatan tidak dapat diguna kan dengan baik. Dari kegiatan diskusi pada pendidikan dan pelatihan kepala laboratorium sekolah diperoleh empat informasi penting yaitu: 1). laboratorium belum dapat difungsikan dengan optimal, 2). kurangnya peralatan untuk mendukung kegiatan eksperimen, 3). peralatan yang ada tidak dapat dioperasikan, dan 4). terba tasnya waktu untuk mengelola kegiatan eksperi men di laboratorium. Adanya kondisi-kondisi nyata ini menyebabkan kegiatan eksperimen tidak dapat dilaksanakan.

Suatu alternatif solusi dari permasalahan ini adalah mengembangkan kegiatan eksperimen fisika melalui analisis video dan tool pemodelan tracker. Solusi ini dipandang relevan dengan pendidikan abad ke-21 karena siswa dilatih menerapkan teknologi digital untuk menguasai fisika. Dalam eksperimen siswa dilatih menggu nakan handphone untuk merekam peristiwa fisika, memindahkan hasil rekaman pada kompu ter, menganalisis hasil rekaman dengan software tracker dan menganalisis lebih lanjut. Disisi lain keterbatasan dari solusi ini adalah kegiatan eksperimen hanya dapat dilakukan pada peris tiwa gerak benda, namun peristiwa gerak baik benda maupun makhluk hidup banyak ditemu kan dalam kehidupan sehari-hari.

Tracker adalah suatu analisis video dan alat pemodelan yang dibangun pada fisika sumber terbuka dengan kerangka kerja java (Brown, 2009; Wee, 2015). Dengan kata lain software tracker dapat didownload secara bebas dan digunakan pada suatu piranti komputer (Firdaus, 2017). Tracker merupakan suatu cara yang hebat dan inovatif untuk menggabungkan antara video dengan model komputer. Software ini didukung oleh sumber daya digital yang menyediakan suatu hubungan ke tutorial dan video yang siap untuk dianalisis (Gregorio, 2015). Bertitik tolak pada ketiga pengertian ini dapat dinyatakan bahwa tracker merupakan suatu software yang dapat digunakan untuk menganalisis video gerak dari suatu benda.

Tracker dirancang untuk digunakan dalam pembelajaran fisika dan dapat digunakan dengan mudah (Repnik, 2015). Dengan menggunakan analisis video dan tool pemodelan siswa dapat menyelidiki bagaimana pusat massa berubah posisi, kecepatan dan percepatan dengan waktu (Hockicko, 2011). Tracker menyediakan suatu bayangan dan suatu software analisis video yang cocok sebagai sebagai alat bantu untuk mengan tarkan konsep-konsep fisika dalam ruang kelas. Kekuatan dari tracker terletak pada kenyataan bahwa seseorang dapat memvisualisasikan kon sep tersebut dalam waktu real (Eddy, 2016).

Pembelajaran didasarkan video mengguna kan analisis video tracker adalah suatu ide yang bagus untuk dikembangkan dalam kelas pem belajaran fisika. Metoda ini dapat dijadikan sebagai alternatif kegiatan eksperimen yang kekurangan atau ketiadaan peralatan laborato rium. Tracker mempunyai kemampuan untuk menyediakan banyak cara kepada pengguna dari suatu cara representasi data. Software tracker menyediakan tool-tool dari representasi banyak dari data eksperimen. Analisis pelacakan video menggunakan software tracker seharusnya juga mampu melatih keterampilan representasi banyak dalam konteks fisika (Anissofira, 2017).

Secara umum tracker mendefinisikan dua tipe dasar model partikel yaitu analisis dan dinamis. Model partikel dinamis dapat dinyata kan dalam cartesian, polar atau sistem dua benda yang mengalami gaya internal dan eksternal. Semua model yang dibangun menggunakan pembangun model tracker menyediakan kontrol untuk mendefinisikan berbagai parameter, 
kondisi awal, dan posisi atau ekspresi gaya (Wijayanto, 2015).

Analisis video menggunakan program tracker sebagai fisika sumber terbuka dalam proses pendidikan mengenalkan metode kreatif baru dalam pembelajaran fisika, membuat ilmu pengetahuan alam lebih menarik bagi siswa. Menjelajahi hukum-hukum alam dengan cara ini dapat menjadi luar biasa bagi siswa karena software pendidikan ini ilustratif, interaktif, mengilhami mereka untuk berpikir kreatif, meningkatkan kinerja mereka dan dapat mem bantu dalam mempelajari fisika. Dengan bantu an kamera berkecepatan tinggi untuk persiapan file gerak benda dengan video eksperimen prog ram tracker, siswa dapat mempelajari gerak tertentu secara lebih mendalam. Analisis video memberi siswa cara sederhana dan mudah untuk memahami proses pergerakan dari benda. Prog ram tracker kelihatannya alat pemodelan yang berguna dalam pendidikan (Hockicko, 2011).

Melalui software tracker, guru dapat memfasilitasi siswa dalam menangkap video gerak dan mengganalisisnya. Siswa secara seder hana memasukkan suatu file video kedalam program telah tersedia pada komputer dan meng observasinya gerak dari benda untuk menganali sis gerak benda tersebut. Melalui program ini siswa juga dapat menangkap video dari suatu peristiwa kehidupan dan menganalisis dengan mudah menggunakan software ini (Firdaus, 2017). Analisis video tracker menawarkan beberapa peluang untuk mendiskusikan keter batasan dan menyempurnakan pengukuran yang ditemukan siswa seperti menjaga kamera pada suatu posisi dan orientasi tetap (Zwickl, 2015)

Analisis video dan pemodelan membantu siswa memahami prinsip-prinsip ilmu pengeta huan alam dan fenomena alam secara lebih men dalam, mengembangkan keterampilan abstraksi dan proyeksi, menimbulkan rasa ingin tahu terhadap alam dan dunia sekitarnya sehingga membuat fisika menjadi lebih menyenangkan. Cara ini mengeksplorasi hukum alam yang dapat memukau siswa karena software pendidikan yang ilustratif dan interaktif ini dapat meng ilhami mereka untuk berpikir kreatif, meningkat kan kinerja mereka dan membantu mereka dalam mempelajari fisika (Hockicko, 2014).

Penggunaan analisis video didasarkan pada tugas-tugas dalam fisika dapat memberikan pengaruh yang berarti dalam pengetahuan ketika siswa memecahkan tugas-tugas biasa dari buku teks cetak (Hockikco, 2015). Disisi lain peng gunaan tracker sebagai suatu sumber terbuka bebas dari analisis video dan peralatan pemodel an digunakan sebagai suatu tool pedagogik untuk pembelajaran efektif pada siswa kelas 9 di sekolah Singapura untuk membuat pembelajaran relevan dengan dunia nyata (Wee, 2015). Penggunaan peralatan praktis yang dikombinasi kan dengan teknologi ini dipercaya untuk menciptakan strategi pembelajaran fisika yang lebih efektif, menarik dan menyenangkan. Eksplorasi konsep-konsep gerak kinematika dipercaya menyediakan suatu penguasaan yang lebih baik apabila diajarkan pada tingkat yang relevan (Wijayanto, 2015).

Ada beberapa penelitian yang telah dilakukan untuk menyelidiki pengaruh penggu naan analisis video dalam pembelajaran fisika. Hasil penelitian pertama adalah analisis video memperkenankan siswa untuk menghubungkan konsep-konsep fisika yang abstrak pada kehidup an nyata melalui pemodelan komputer menjadi dengan analisis video dapat dijadikan suatu cara efektif untuk mempelajari gerak parabola (Wee, 2012). Hasil penelitian kedua adalah pengguna an analisis video dan tool pemodelan dapat digunakan untuk membuat pendidikan fisika relevan dengan dunia nyata dan membantu pengalaman siswa berlatih seperti ilmuwan dan meningkatkan tugas kinerjanya (Wee, 2015). Hasil penelitian ketiga adalah kompetensi siswa dapat dikembangkan dan pengetahuan mereka dapat ditingkatkan dengan bekerja mengguna kan program tracker (Hockicko, 2014). Hasil penelitian keempat adalah penggunaan metoda analisis video menggunakan program tracker telah mengungkapkan bahwa metoda interaktif ini adalah lebih mudah bagi siswa, menarik bila mereka merekam dan menganalisis videonya sendiri, dan mereka dapat mengatur kecepatan individu untuk pekerjaannya (Hockicko, 2011). Hasil penelitian terakhir adalah nilai rata-rata percepatan gravitasi bumi yang diperoleh dari aplikasi tracker adalah 9,676 $\mathrm{m} / \mathrm{dt}^{2}$ sehingga aplikasi tracker dapat dijadikan sebagai salah satu metode alternatif untuk memperoleh nilai percepatan gravitasi bumi dalam pembelajaran fisika SMA (Afifah, 2015).

Penggunaan software tracker telah membe rikan beberapa kemudahan dan keuntungan dalam pembelajaran Fisika. Mengingat adanya permasalahan guru-guru Fisika dalam melaksa nakan kegiatan eksperimen di laboratorium, maka analisis video dan tool pemodelan merupakan suatu alternatif dari pemecahan 
masalah tersebut. Dengan alasan ini, peningkat an pengetahuan dan keterampilan guru fisika dalam merancang dan menggunakan analisis video dan tool pemodelan tracker adalah penting bagi guru-guru Fisika. Tujuan dari penelitian adalah untuk menyelidiki hasil-hasil dari pelaksa naan pelatihan analisis video dan tool pemodel an tracker pada guru MGMP Fisika.

\section{METODE PENELITIAN}

Jenis penelitian yang dilakukan adalah penelitian eksperimen semu. Desain penelitian adalah pretes-postes untuk satu kelompok sampel. Dalam desain penelitian, satu kelompok sampel diberikan perlakuan dan dilihat efek dari perlakuan tersebut. Sebelum diberikan perlakuan kepada kelompok sampel diberikan postes untuk mengetahui pengetahuan awal dari sampel. Setelah menerapkan perlakuan diberikan postes untuk mengetahuai penguasaan akhir sampel. Efektivitas dari perlakuan dapat ditentukan dari perbandingan hasil postes dan hasil pretes.

Sebagai populasi dari penelitian adalah seluruh guru Fisika yang menjadi anggota MGMP Fisika kabupaten Agam. Sampel dari penelitian adalah guru fisika yang mengikuti kegiatan pelatihan dengan penuh. Jumlah sampel dari adalah 26 guru Fisika MGMP kabupaten Agam.

Instrumen yang digunakan untuk mendapat kan data terdiri dari tiga bagian. Instrumen pertama adalah lembar tes pengetahuan. Bentuk tes yang digunakan adalah menjodohkan dengan 20 buah soal. Tes ini digunakan untuk menge tahui penguasaan guru tentang software tracker sebelum mengikuti pelatihan dan setelah meng ikuti pelatihan. Instrumen kedua adalah lembar penilaian kinerja. Lembar penilaian ini diguna kan untuk menilai produk yang dihasilkan oleh guru pada selama kegiatan pelatihan. Komponen penilaian terhadap produk dari guru terdiri dari dua bagian produk video dan analisis video dengan tracker. Indikator penilaian produk analisis video terdiri atas delapan yaitu: video yang dibuat, tampilan video, tampilan video, kebenaran langkah analisis, tampilan grafik, kebenaran grafik, kebenaran data, dan kelengkap an analisis. Instrumen ketiga adalah lembar angket tanggapan guru terhadap pelaksanaan pelatihan. Lembar angket ini digunakan untuk mengetahui tanggapan guru setelah mengikuti kegiatan pelatihan. Indikator dari instrumen mencakup: gambaran terhadap kegiatan laborato rium fisika, pembuatan video gerak benda, analisis video dengan software tracker, kontri busi hasil pelatihan, dan penyusunan LKS dengan analisis video.

Data yang diperoleh dari instrumen diana lisis dengan statistik yang sesuai. Teknik analisis data yang digunakan meliputi analisis statistik deskriptif, uji normalitas dan uji homogenitas dan uji perbandingan dipasangkan. Analisis statistik deskriptif digunakan untuk mendeskrip sikan sekelompok data pretes, postes, nilai produk dan tanggapan guru seperti nilai minimum, nilai maksimum, nilai rata-rata, standar deviasi, varians. Analisis statistik juga digunakan untuk mendeskripsikan sekelompok data nilai produk dan tanggapan guru dalam bentuk tabel. Uji normalitas digunakan untuk distribusi dari sekelompok data pretes dan postes. Uji homogenitas digunakan untuk menen tukan kesamaan varians dari dua kelompok data dari pretes dan postes. Disisi lain, uji perban dingan dipasangkan digunakan untuk menentu kan perbedaan nilai postes dengan nilai pretes jika kelompok data terdistribusi secara normal dan kedua kelompok data mempunyai variasi yang sama. Jika kondisi ini tidak dipenuhi, maka uji perbandingan dipasangkan Wilcoxon untuk statistik non parametrik dapat digunakan.

\section{HASIL DAN PEMBAHASAN}

\section{Hasil Penelitian}

Hasil penelitian yang diperoleh berhu bungan dengan tujuan dan data yang telah dikumpulkan. Berdasarkan analisis data yang telah dilakukan dapat dikemukakan hasil dari penelitian ini. Ada tiga hasil dari studi yang telah dilakukan yaitu: nilai produk analisis video gerak benda, nilai tanggapan guru fisika terhadap pelaksanaan pelatihan analisis video dan tool pemodelan serta efektivitas pelaksanaan pelatihan pada penguasaan materi guru fisika.

Hasil pertama dari penelitian adalah produk hasil analisis video. Produk yang dihasilkan oleh peserta adalah analisis video dari gerak benda. Proses yang dilakukan peserta dalam menganalisis video adalah merekam gerak benda, mengambil file video hasil rekam an, menyimpan hasil rekamam video pada folder yang ditetapkan, membuka software tracker, mengganalisis video dengan beberapa langkah, memindahkan hasil analisis video pada micro soft word dan melakukan analisis lebih lanjut. Peserta juga diminta untuk merekam video dari 
gerak benda di laboratorium dan gerak benda dalam kehidupan sehari-hari.

Pada pertemuan terakhir peserta pelatihan diminta mengumpulkan produk kegiatan berupa hasil analisis video dari gerak benda. Dalam kegiatan pelatihan, ada 13 produk analisis video gerak benda yang dihasilkan oleh peserta dari MGMP fisika kabupaten Agam. Analisis video gerak benda yang dapat dihasil kan oleh peserta adalah gerak lurus beraturan dan berubah beraturan, gerak melingkar gerak parabola, gerak jatuh bebas, dan ayunan bandul sederhana. Hasil penilaian dari produk peserta untuk MGMP Fisika kabupaten Agam diperlihatkan pada Gambar 1

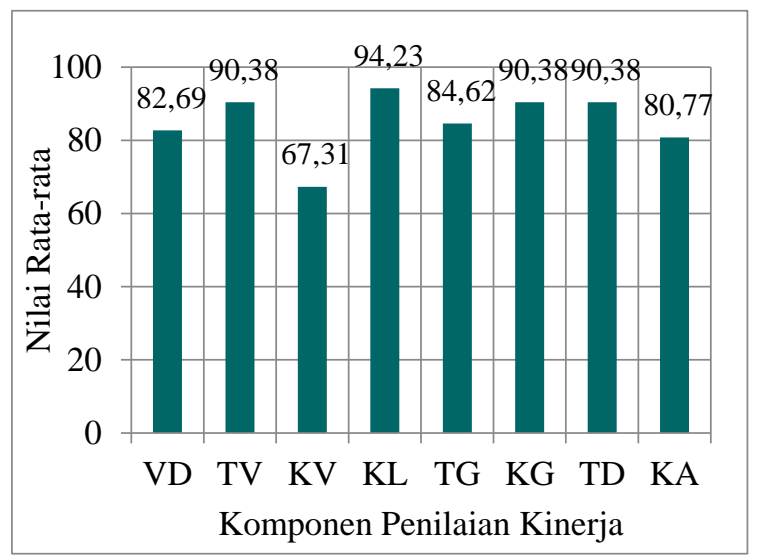

Gambar 1. Penilaian Kinerja Peserta

Nilai analisis video peserta dari MGMP fisika kabupaten Agam bervariasi dari 67.31 sampai 94.23. Indikator dengan nilai lebih dari 90 adalah tampilan video, kebenaran langkah analisis, kebenaran grafik, dan tampilan data. Indikator dengan nilai antara 80 sampai 90 adalah video yang dibuat, tampilan grafik, dan kelengkapan analisis. Sementara itu nilai indi kator kreativitas video adalah 67,31. Kreativitas video disini adalah peserta menghasilkan video diluar peristiwa gerak yang disediakan dalam pelatihan seperti video gerak benda yang diambil pada laboratorium sekolah dan gerak dalam kehipan sehari-hari. Nilai rata-rata produk analisis video adalah 85,10 dan nilai ini dapat diklasifikan kedalam kategori sangat baik.

Hasil kedua dari penelitian adalah kepuasan dari peserta terhadap pelaksanaan kegiatan pelatihan. Nilai tanggapan peserta terhadap kegiatan pelatihan peningkatan proses sains didapat dari angket. Angket diberikan kepada peserta pada akhir kegiatan. Secara umum angket terdiri atas lima komponen yaitu kegiatan laboratorium fisika, pembuatan video gerak benda, analisis video dengan software tracker, kontribusi hasil pelatihan, dan penyu sunan LKS fisika. Setiap komponen terdiri dari lima pernyataan. Hasil penilaian dari tanggapan peserta MGMP fisika kabupaten Agam diperli hatkan pada Gambar 2

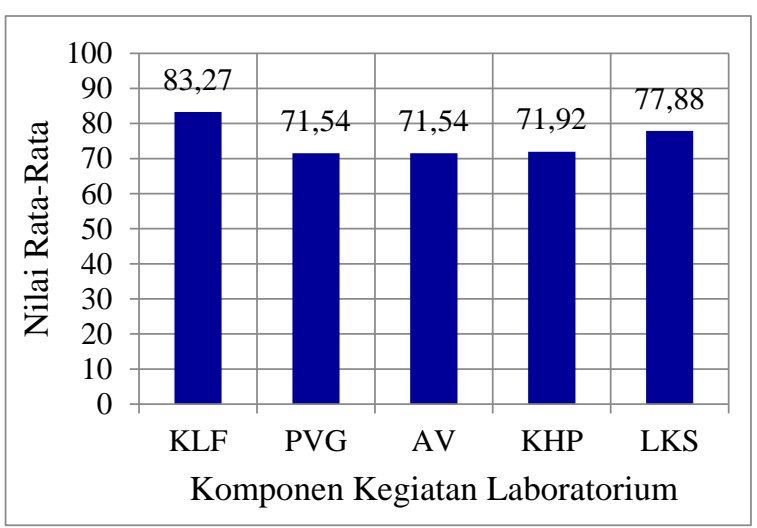

Gambar 1. Nilai Kepuasan Guru Fisika

Berdasarkan hasil analisis grafik pada Gambar 2 dapat dideskripsikan bahwa nilai tanggapan peserta MGMP kabupaten Agam bervariasi dari 66,73 sampai 83,27. Nilai tanggapan peserta pada komponen kegiatan laboratorium adalah 83,27 dan nilai ini dapat dikelompokkan pada kategori sangat baik. Artinya peserta merasa mendapatkan gambar berbagai kegiatan yang dapat dilakukan untuk meningkatkan proses sains di laboratorium fisika. Nilai komponen yang sudah termasuk pada kategori baik adalah pembuatan video gerak benda, analisis video dengan software tracker, konstribusi hasil pelatihan pada kegiatan laboratorium, dan penyusunan LKS fisika. Artinya peserta merasa sudah mampu melaku kan berbagai kegiatan yang dapat digunakan untuk meningkatkan kualitas proses sains di laboratorium fisika. Nilai rata-rata dari keenam komponen kegiatan proses sains ini adalah 73,81 dan nilai rata-rata ini dapat dimasukkan kedalam kategori baik.

Hasil ketiga dari penelitian adalah efektivitas pelatihan analisis video dan tool pemodelan. Efektivitas pelatihan dilihat dari penguasaan peserta terhadap software tracker sebelum dan setelah pelatihan. Dalam pelatihan pretes tentang materi yang berhubungan dengan software tracker diberikan kepada peserta pelatihan. Setelah pelaksanaan pelatihan diberi kan postes kepada peserta.

Hasil pretes dan postes diolah mengguna kan untuk mendapatkan parameter statistik 
dekriptif dari sekelompok data pretes dan postes. Data pretes dan postes juga dianalisis untuk mengetahui normalitas dan kesamaan varians dari kelompok data. Disamping itu, kedua data dianalisis menggunakan uji perbandingan dipa sangkan untuk menentukan perbedaan penguasa an peserta setelah dan sebelum pemberian perlakuan. Nilai-nilai parameter statistik dari analisis data diperlihatkan pada Tabel 1 .

Tabel 1. Nilai Parameter Statistik dari Data

\begin{tabular}{|c|l|c|}
\hline No & \multicolumn{1}{|c|}{ Parameter Statistik } & Nilai \\
\hline 1 & nilai rata-rata pretes & 29,23 \\
\hline 2 & standar deviasi pretes & 11,81 \\
\hline 3 & nilai rata-rata postes & 54,42 \\
\hline 4 & standar deviasi postes & 16,27 \\
\hline 5 & nilai P uji normalitas pretes & 0,186 \\
\hline 6 & nilai P uji normalitas postes & 0,005 \\
\hline 7 & nilai P dari uji F & 0,116 \\
\hline 8 & $\begin{array}{l}\text { nilai uji perbandingan } \\
\text { dipasangkan Wilcoxon }\end{array}$ & $-4,413$ \\
\hline
\end{tabular}

Nilai rata-rata pretes penguasaan peserta terhadap software tracker adalah 29,23. Nilai rata-rata ini bereda pada kategori sangat rendah. Disisi lain nilai rata-rata postes adalah 54,42. Nilai rata-rata postes berada pada kategori rendah. Data ini mengisyaratkan bahwa pelaksa naan pelatihan analisis video dengan software tracker dapat meningkatkan pengausaan peserta terhadap materi tracker tetapi nilai rata-rata postes masih berada pada kategori cukup.

Karakteristik dari kelompok data ditentu kan dari uji normalitas dan uji homogenitas. Dari uji normalitas didapatkan nilai $\mathrm{p}$ dari pretes dan postes masing-masing 0,186 dan 0,005 . Untuk nilai taraf nyata $\alpha=0,05$ berarti nilai $P$ dari pretes lebih besar dari nilai taraf nyata data pretes terdistribusi secara normal, sedangkan nilai $\mathrm{P}$ dari postes lebih kecil dari nilai taraf nyata sehingga data postes tidak terdistribusi secara normal. Disisi lain dari uji homogenitas didapatkan nilai $F=0.116$. Nilai $F$ ini lebih besar dari nilai taraf nyata yang ditetapkan sehingga kelompok data pretes dan postes mempunyai variansi yang sama.

Dari uji normalitas dan uji homogenitas ternyata salah satu dari kelompok data pretes dan postes adalah tidak terdistribusi secara normal sedangkan kedua kelompok data mempunyai variansi yang sama. Berarti kedua kelompok data tidak memenuhi statistik parametrik. Dengan alasan ini, uji perbedaan penguasaan guru terhadap materi tracker ditentu kan menggunakan statistik non parametrik yaitu uji perbandingan dipasangkan Wilcoxon. Nilai $t$ hitung dari uji statistik ini didapatkan $\mathrm{t}=-4,41$. Pada taraf nyata $\alpha=0.05$, setengah dari nilai taraf nyata adalah 0.025 , maka luas daerah dibawah kurva $F(z)=0.475$ sehingga diperoleh nilai $\mathrm{Z}$ dalam tabel adalah 1.90 . Berarti nilai $\mathrm{Z}$ hitung berada di luar daerah penerimaan hipotesis nol. Hasil uji hipotesis mengindikasi kan bahwa terdapat perbedaan penguasaan materi software tracker dari peserta antara setelah dengan sebelum pelaksanaan pelatihan analisis video dan tool pemodelan. Dengan demikian pelaksanaan pelatihan analisis video dan tool pemodelan dari gerak benda mengguna kan software tracker adalah efektif untuk meningkatkan penguasaan peserta pelatihan terhadap materi tracker.

\section{Pembahasan}

Pelaksanaan pelatihan analisis video dan tool modeling menggunakan software tracker telah memberikan tiga hasil utama. Hasil pertama adalah guru MGMP Fisika kabupaten Agam telah mampu menganalisis video gerak benda dengan software tracker. Hal ini ditandai dengan produk hasil analisis video gerak benda yang telah dihasilkan.

Setidaknya ada empat alasan guru Fisika MGMP kabupaten Agam mampu menghasilkan menghasilkan produk analisis video dengan software tracker. Pertama, analisis video dan tool pemodelan tracker merupakan suatu sumber yang tersedia bebas sehingga mudah didapat dan digunakan dalam pendidikan fisika. Software tracker bekerja dalam kerangka kerja Java (Wee, 2015). Kedua, pada bantuan software atau tutorial tracker sudah ada langkah-langkah yang jelas untuk menganalisis video gerak benda. Secara umum langkah analisis video mencakup: buka suatu video atau file tracker, identifikasi kerangka atau potongan video yang diinginkan, kalibrasi skala video, set kerangka referensi awal dan sudut, track objek yang diinginkan dengan mouse, plot dan analisis track, simpan hasil pekerjaan dalam suatu file tracker, ekspor data track pada suatu spreadsheet, dan print atau copy bayangan untuk laporan. Ketiga, peristiwa gerak benda banyak ditemukan dalam kehidupan sehari-hari dan peralatan laboratorium fisika sekolah. Keempat, umumnya guru fisika sudah memiliki handphone yang bagus untuk membuat video gerak benda dan komputer untuk meng analis video gerak dengan software tracker. 
Hasil kedua yang telah dicapai adalah guru Fisika MGMP kabupaten Agam yang mengikuti pelatihan merasa puas terhadap pelak sanaan pelatihan analisis video dan hasil yang diperoleh. Kepuasan ini dapat diperhatikan dengan nilai rata-rata tanggapan guru terhadap lima komponen yang berhubungan dengan ke giatan berada pada kategori baik.

Adanya kepuasan dari guru-guru fisika ini diperkirakan karena kemudahan dan keunggulan dari software tracker untuk menjelaskan pola hubungan antara besaran fisika dan menentukan nilai dari besaran fisika. Keunggulan dari software tracker antara lain: memberikan cara sederhana dan mudah untuk memahami proses pergerakan benda (Hockicko, 2011), menyedia kan representasi banyak dari data eksperimen (Annisofira, 2017), mampu menangkap video dari suatu peristiwa kehidupan dan menganalisis nya dengan mudah (Firdaus, 2017), membantu memahami prinsip-prinsip dan fenomena alam secara lebih mendalam serta membuat fisika lebih menarik (Hockicko, 2013). Guru fisika yang telah menggunakan software ini tentu merasakan adanya kemudahan dan keunggulan software untuk menganalisis video gerak benda.

Hasil terakhir yang telah dicapai adalah pelaksanaan pelatihan analisis video adalah efektif untuk meningkatkan penguasaan guru MGMP fisika kabupaten Agam terhadap materi tracker. Hal ini ditandai dengan adanya pening katan penguasaan dari guru-guru fisika terhadap materi tracker antara setelah dengan sebelum pelaksanaan pelatihan. Salah satu cara menentu kan efektivitas dari intervensi pada aspek pengetahuan adalah membandingkan hasil postes dengan pretes (Asrizal, 2017). Terjadi nya peningkatan penguasaan guru ini disebab kan oleh beberapa faktor seperti telah mem pelajari materi, telah mengalami proses analisis video, telah mendapatkan hasil dari analisis video dan sebagainya.

Dalam pelaksanaan pelatihan analisis video menggunakan software tracker ditemukan beberapa keterbatasan dan kelemahan. Keterba tasan dan kelemahan pertama adalah produk hasil analisis video yang dihasilkan oleh guru fisika umumnya berasal dari tool pemodelan fisika yang telah disediakan. Dalam pelatihan guru-guru fisika diharapkan dapat membuat video dari gerak benda yang berasal dari kehidupan sehari-hari dan peralatan fisika yang tersedia di laboratorium sekolah masing-masing. Keterbatasan dan kelemahan kedua adalah tindak lanjut kegiatan analisis yang dilakukan baru pada transfer data pada Microsoft excel dan konversi grafik dan data pada microsoft word serta menganalisis dan menginterpretasikannya. Keterbatasan dan kelemahan ketiga adalah pelak sanaan pelatihan analisis video belum mampu meningkatkan penguasaan guru terhadap materi tracker pada kategori baik atau sangat baik. Penyebab rendahnya penguasaan ini diperkira kan antara lain: penggunaan istilah dan instruksi dalam bahasa Inggris, belum mempelajari bantuan dan tutorial tracker dengan baik dan kurang menghubungkan langkah-langkah pada analisis video dengan materi tracker. Solusi alternatif yang dapat dilakukan untuk mengatasi keterbatasan dan kelemahan dari pelaksanaan dan hasil yang dicapai dalam pelatihan ini antara lain: menyusun bahan ajar pelatihan analisis video, menerapkan metode penelitian dan model pelatihan yang relevan, meningkatkan kerjasama pimpinan sekolah, dan menyusun lembar kerja siswa berdasarkan analisis video gerak benda.

\section{KESIMPULAN}

Berdasarkan analisis data yang telah dilakukan dan hasil yang didapatkan dapat dikemukan kesimpulan dari studi ini. Ada tiga kesimpulan dari studi yaitu:

1. Nilai rata-rata produk analisis video dari peserta MGMP fisika kabupaten Agam adalah 85,10 . Nilai rata-rata produk analisis video gerak benda ini berada pada kategori sangat baik.

2. Nilai rata-rata tanggapan peserta MGMP fisika kabupaten Agam tentang kegiatan untuk mendukung proses sains di laborato rium, pembuatan video gerak benda, analisis video dengan software tracker, praktek laboratorium virtual, kontribusi hasil pelatih an dan penyusunan LKS fisika adalah 73,81. Nilai rata-rata ini berada pada kategori baik. Berarti peserta merasa puas terhadap pelaksa naan pelatihan analisis video dan yakin dapat menerapkan hasil pelatihan di sekolah mereka masing-masing.

3. Pelaksanaan pelatihan analisis video dari gerak benda menggunakan software tracker adalah efektif untuk meningkatkan penguasa an guru MGMP Fisika kabupaten Agam ter hadap materi analisis video dan tool pemodel an tracker, tetapi nilai rata-rata pengusaan materi masih berada pada kategori rendah. 


\section{DAFTAR PUSTAKA}

Afifah, D. N., Yulianawati, D. (2015). Metode Sederhana Menentukan Percepatan Gravi tasi Bumi Menggunakan Aplikasi Tracker Pada Gerak Parabola Sebagai Media dalam Pembelajaran Fisika SMA. Prosi ding Simposium Nasional Inovasi dan Pembelajaran Sains 2015 (SNIPS), Bandung, Indonesia

Anissofira, A., ett, all. (2017). Newton's Cradle Experiment Using Video Tracking Analysis with Multiple Representation Approach. International Conference on Mathematics and Science Education (ICMScE), IOP Conf. Series: Journal of Physics: Conf. Series 895

Asrizal, Amran, A., Ananda, A., and Festiyed. (2017). Effectiveness of Integrated Science Instructional Material on Pressure in Daily Life Theme to Improve Digital Age Literacy of Students. Journal of Physics: Conference Series, Volume 1006, Conference 1

Brown, Douglas and Cox, Anne J. (2009). Innovative Uses of Video Analysis. The Physics Teacher Journal. Vol. 47

Eddy Yusuf. 2016. Using Tracker to Engage Students' Learning and Research in Physics. Pertanika Journal Science and Technology, 24 (2), 483-491

Giambattista, Alan., Richardson, Betty McCharty., and Richardson, Robert C. (2010). College Physics: With an Integrated Approach to Force and Kinematics. Third Edition, McGraw-Hill Companies, Inc, New York

Gregario, Jay B. (2015). Using Video Analysis, Microcomputer-Based Laboratories (MB L's) and Educational Simulations as Pedagogical Tools in Revolitionizing Inquiry Science Teaching and Learning. K-12 STEM Education, Vol. 1, No. 1, pp.43-64

Halliday, David., Resnick, Ribert., Walker, Jearn. (2011). Fundamental of Physics. $9^{\text {th }}$ Edition. John Wiley \& Sons, Inc, United States of America.

Hockicko, Peter. 2015. Development of Students' Conceptual Thinking by Means of Video Analysis and Interactive Simula tions at Technical Universities. European Journal of Engineering Education, Vol.40 No.2 P.145-166

Hockicko, Peter. 2015. Video Analysis Based Tasks in Physics. Proceeding of the Girep
MPTL Conference, University of Palermo, Italy

Hockicko, Peter. 2011. Forming of Physical Knowledge in Engineering Education with the Aim to Make Physics more Attractive. Physics Teaching in Engi neering Education

Hockicko, P. 2014. Video Analysis of Motions.

Department of Physics Faculty of Electrical Engineering University of Zilina, Slovakia

Firdaus, T., Setiawan, W., and Hamidah, I. (2017). The Kinematic Learning Model Using Video and Interfaces Analysis. International Conference on Mathematics and Science Education (ICMScE), IOP Conf. Series: Journal of Physics: Conf. Series 895,012108

Repnik, Robert., Robic, Dominic and Pesek, Igor. (2015). Physics Learning in Primary and Secondary Schools with Computer Games-An Example-Angry Birds. Intech Open Science.

Serway, Raimond. A., Vuelle, Chris. (2012). College Physics. Ninth Edition, Charles Hartford, United States of America.

Wee, Loo Kang, ett all. (2012). Using Tracker as a Pedagogical Tool for Understanding Projectile Motion. Physics Education Journal, P 448-455

Wee, Loo Kang, ett all. (2012). Using Tracker to Understand 'Toss Up' and Free Fall Motion: a Case Study. Physics Education Journal, 50 (4)

Wee, Loo Kang., Kwang, Wee1 Tze. (2015). Video Analysis and Modeling Performan ce Task to Promote Becoming Like Scientists in Classrooms. American Journal of Educational Research SciEP, Volume 3, Issue 2, Pages: 197-2007

Widiyanto, Susilawati. (2015). Rancangan Kine matika Gerak Menggunakan Alat Ekspe rimen Air Track untuk Media Pembe lajaran Fisika Berbasis Video. Jurnal Informatika UPGRIS, Volume 1, No 2

Young, Hugh. D. (2012). College Physics. $9^{\text {th }}$ Edition, Addison-Wesley

Zitzewitz, Paul. G. (2005). Physics: Principles and Problems. The McGraw-Hill Compa nies, Inc, United States of America.

Zwickl, Benjamin M and Dehui Hu. (2015). Model-Based Reasoning in the UpperDivision PhysicsLaboratory: Framework and Initial Results. School of Physics and Astronomy, Rochester Institute of Techno logy, Rochester 